\title{
Interleukin-1 $\beta$ weakens paclitaxel sensitivity through regulating autophagy in the non-small cell lung cancer cell line A549
}

\author{
JUANWEN LIAN*, TAO HUA ${ }^{*}$, JIALING XU, JIE DING, ZEJIE LIU and YU FAN \\ Department of Oncology, Xi'an Chest Hospital, Xi'an, Shaanxi 710100, P.R. China
}

Received May 15, 2020; Accepted December 15, 2020

DOI: $10.3892 /$ etm.2021.9724

\begin{abstract}
Non-small cell lung cancer (NSCLC) poses a threat to human health and paclitaxel chemotherapy has been approved for the treatment of this type of cancer. However, resistance to treatment severely compromises the survival rate and prognosis of patients with NSCLC. The aim of the present study was to investigate the role of IL- $1 \beta$ in paclitaxel sensitivity of NSCLC cells and elucidate the underlying mechanism. The expression of IL-1 $\beta$ was found to be upregulated in NSCLC tissues and cells compared with healthy adjacent tissues and a normal epithelial cell line, respectively, as detected by reverse transcription-quantitative PCR and western blot analyses. Subsequently, Cell Counting Kit- 8 assay and flow cytometry revealed that IL-1 $\beta$ weakened the sensitivity of A549 cells to paclitaxel. It was subsequently demonstrated that IL-1 $\beta$ induced A549 cell autophagy, while tunicamycin-induced autophagy increased the IL-1 $\beta$ expression level and weakened paclitaxel sensitivity. Thus, the results revealed that IL-1 $\beta$ reduced the sensitivity to paclitaxel in A549 cells by promoting autophagy and suggested that IL-1 $\beta$ may be of value for improving the therapeutic efficacy of paclitaxel chemotherapy in NSCLC.
\end{abstract}

\section{Introduction}

Non-small cell lung cancer (NSCLC) is a major subtype of lung cancer, accounting for $11.6 \%$ of all new cancer cases and $18.4 \%$ of all cancer-associated mortalities in 2018 worldwide (1). Surgery, chemotherapy, radiation therapy and targeted therapy are currently the main options for NSCLC treatment (2). To date, platinum-based chemotherapy remains the standard treatment for the majority of patients with advanced NSCLC (3). Despite the improved understanding of tumor progression and

Correspondence to: $\mathrm{Dr} \mathrm{Yu}$ Fan, Department of Oncology, Xi'an Chest Hospital, East Section of Hangtian Avenue, Xi'an, Shaanxi 710100, P.R. China

E-mail: 1f85325060@163.com

${ }^{*}$ Contributed equally

Key words: non-small cell lung cancer, IL-1 $\beta$, paclitaxel, drug sensitivity, autophagy therapy, the overall survival rate remains low, particularly for patients with metastatic disease (4). Therefore, it is urgent to improve cure rate and prognosis of patients with NSCLC.

Paclitaxel, also known as Taxol/Tax, is a natural diterpene alkaloid initially extracted from the bark of the Taxus brevifolia tree. The mechanism of action of paclitaxel is inducing cell cycle arrest and cell death by stabilizing microtubules and interfering with microtubule disintegration during cell division (5). Paclitaxel has been approved by the Food and Drug Administration for the treatment of several types of cancer, including ovarian, breast and lung cancer, and Kaposi's sarcoma (6). The combination of paclitaxel and platinum chemotherapy has also been approved for the treatment of advanced NSCLC (7). In addition, paclitaxel as a single agent also exhibits similar antitumor efficiency in the second-line setting (8). However, accumulating evidence indicates that the therapeutic efficacy of paclitaxel is compromised by drug resistance (9). Therefore, there is an urgent need to elucidate the underlying mechanism in order to overcome drug resistance and improve the efficacy of paclitaxel.

IL-1 $\beta$, one of the isoforms of IL-1, is a pro-inflammatory cytokine that is secreted in response to inflammatory stimuli, and aggravates the tissue injury caused by acute and chronic diseases $(10,11)$. IL-1 $\beta$ is mainly produced by myeloid cells and its expression is increased under disease conditions (12). Previous studies have demonstrated that IL- $1 \beta$ plays a key role in various inflammatory diseases, including lung cancer (13). High serum IL-1 $\beta$ level in NSCLC is associated with short overall survival (14). In addition, IL-1 $\beta$ is associated with resistance to cancer drugs, such as cisplatin (15), 5-fluorouracil (16) and imatinib (17). However, to the best of our knowledge, the association between IL-1 $\beta$ and paclitaxel resistance in NSCLC remains largely unknown.

The aim of the present study was to investigate the role of IL-1 $\beta$ in Paclitaxe resistance of NSCLC cells. The expression of IL-1 $\beta$ in lung cancer tissues and cells was detected, and the effects of IL-1 $\beta$ on paclitaxel sensitivity and autophagy, as well as the effects of autophagy on paclitaxel sensitivity, were investigated, in order to determine whether IL-1 $\beta$ may be used for modulating the sensitivity of NSCLC to paclitaxel.

\section{Materials and methods}

Tissue samples. A total of 30 paired NSCLC tissues and adjacent normal tissues after resection were collected from Xi'an 
Chest Hospital (Xi'an, China) between January 2017 and June 2018. The tissues were frozen at $-80^{\circ} \mathrm{C}$. There were 19 males and 11 females, with a mean age of 62 years (range, 41-74). The distance between the normal and the lung cancer tissue was $>3 \mathrm{~cm}$. None of the patients who participated in the present study had received any treatment prior to surgery. Written informed consent was obtained from each participant and the study protocol was approved by the Ethics Committee of Xi'an Chest Hospital (Xi'an, China).

Cell culture and treatment. The human NSCLC cell lines A549, HCC827 and H1650, and the normal epithelial cell line BEAS-2B, were purchased from American Type Culture Collection. The cells were cultured in RPMI-1640 medium supplemented with $10 \% \mathrm{FBS}$ and $100 \mathrm{mg} / \mathrm{ml}$ streptomycin and $100 \mathrm{U} / \mathrm{ml}$ penicillin (all from Gibco; Thermo Fisher Scientific, Inc.) at $37^{\circ} \mathrm{C}$ with $5 \% \mathrm{CO}_{2}$. A549 cells exposed to different treatments were used for subsequent experiments.

Cell Counting Kit-8 (CCK-8). The CCK-8 assay (Dojindo Molecular Technologies, Inc.) was performed to test cell viability. Following treatment with $8 \mathrm{nM}$ paclitaxel (APeXBIO Technology LLC), $20 \mathrm{ng} / \mathrm{ml}$ recombinant human IL-1 $\beta$ (Sangon Biotech Co., Ltd.), $0.1 \mu \mathrm{g} / \mathrm{ml}$ tunicamycin (Beijing Solarbio Science \& Technology Co., Ltd.), paclitaxel + IL-1 $\beta$, paclitaxel + tunicamycin and blank control, then $2 \times 10^{3}$ A549 cells were seeded into 96 -well plates and incubated at $37^{\circ} \mathrm{C}$ with $5 \% \mathrm{CO}_{2}$ for $48 \mathrm{~h}$. At $0,12,24$ and $48 \mathrm{~h}, 10 \mu \mathrm{l} \mathrm{CCK}-8$ reagent was added to each well and incubated with the cells for $2 \mathrm{~h}$. Absorbance was measured at $450 \mathrm{~nm}$ by a microplate reader (Thermo Fisher Scientific, Inc.).

Flow cytometry. Cell apoptosis was analyzed using an Annexin V-FITC Apoptosis Detection kit (BD Biosciences). A549 cells in the logarithmic growth phase were exposed to different treatments (same as in the CCK- 8 assay) at $37^{\circ} \mathrm{C}$ with $5 \% \mathrm{CO}_{2}$ for $48 \mathrm{~h}$, washed twice with cold PBS and resuspended in binding buffer at a density of $1 \times 10^{6}$ cells $/ \mathrm{ml}$. A total of $5 \mu \mathrm{l}$ Annexin V-FITC and $5 \mu \mathrm{l}$ propidium iodide were added to cells and incubated for $15 \mathrm{~min}$ in the dark at room temperature. Then, $400 \mu \mathrm{l}$ binding buffer was added to each tube. Apoptosis was analyzed using a BD FACSCalibur flow

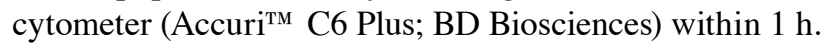

Reverse transcription-quantitative PCR (RT-qPCR) analysis. Total RNA was extracted from paired NSCLC and para-carcinoma tissues and NSCLC cell lines using TRIzol ${ }^{\circledR}$ reagent (Invitrogen; Thermo Fisher Scientific, Inc.) and $1 \mu \mathrm{g}$ of total RNA was reverse-transcribed to cDNA using PrimeScript RT reagent kit at $37^{\circ} \mathrm{C}$ for $15 \mathrm{~min}$ (Takara Bio, Inc.). Subsequently, qPCR was performed using SYBR Premix Ex Taq (Perfect Real Time; Takara Bio, Inc.) and an ABI Prism 7700 Real-Time PCR system (Applied Biosystems; Thermo Fisher Scientific, Inc.). The following thermocycling conditions were used: Initial denaturation for $30 \mathrm{sec}$ at $95^{\circ} \mathrm{C} ; 40$ cycles of $5 \mathrm{sec}$ at $95^{\circ} \mathrm{C}$ and $30 \mathrm{sec}$ at $60^{\circ} \mathrm{C}$; and dissociation for $15 \mathrm{sec}$ at $95^{\circ} \mathrm{C}$, $30 \mathrm{sec}$ at $60^{\circ} \mathrm{C}$ and $15 \mathrm{sec}$ at $95^{\circ} \mathrm{C}$. The specific primers for IL-1 $\beta$ and GAPDH were synthesized by GenScript and the following sequences were used: IL-1 $\beta$ forward, 5'-ATGGCA GAAGTACCTAAGCTC-3'; and reverse, 5'-TTAGGAAGA
CACAAATTGCATGGTGAACTCAGT-3'; GAPDH forward, 5'-TGACTTCAACAGCGACACCCA-3' and reverse, 5'-CAC CCTGTTGCTGTAGCCAAA-3'. The relative expression was calculated using the $2^{-\Delta \Delta \mathrm{Cq}}$ method and presented as fold change (18). GAPDH was used for normalization.

Western blot analysis. Total protein was extracted from tissues and NSCLC cells using ProteoPrep Sample Extraction kit (Sigma-Aldrich; Merck KGaA). The QuantiPro ${ }^{\mathrm{TM}}$ BCA Assay kit (cat. no. QPBCA; Sigma-Aldrich; Merck KGaA) was used to measure protein concentration. Protein samples $(30 \mu \mathrm{g})$ were separated via SDS-PAGE (10\% gel; Bio-Rad Laboratories, Inc.) and transferred to PVDF membranes. The membranes were then blocked with $5 \%$ non-fat milk in TBS with $0.05 \%$ Tween-20 for $1 \mathrm{~h}$ at room temperature. After the membranes were incubated with primary antibodies at $4^{\circ} \mathrm{C}$ overnight, secondary antibodies were added and incubated with the membranes at room temperature for $1 \mathrm{~h}$. The bands were visualized with an ECL Western Blotting substrate kit (cat. no. K820; BioVision, Inc.) and the protein expression was quantified using ImageJ v1.8.0 software (National Institutes of Health) with GAPDH as the loading control. The primary antibodies used included: Mouse anti-IL-1 $\beta$ (1:1,000; cat. no. 12242; Cell Signaling Technology, Inc.), rabbit anti-LC3B (1:1,000; cat. no. ab51520; Abcam), rabbit anti-P62 (1:10,000; cat. no. ab109012; Abcam) and rabbit anti-GAPDH (1:2,500; cat. no. ab9485; Abcam). The corresponding secondary antibodies included: Anti-mouse IgG HRP-conjugated antibody (1;2,000; cat. no. 7076; Cell Signaling Technology, Inc.) and goat anti-rabbit IgG HRP-conjugated antibody (1:20,000; cat. no. ab205718; Abcam).

Statistical analysis. All statistical analyses were performed using GraphPad Prism 5.0 (GraphPad Software, Inc.). Paired Student's t-test was used for measuring IL-1 $\beta$ expression in paired tissues. One-way ANOVA followed by Tukey's post hoc test was performed to evaluate differences between multiple groups. Data are presented as the mean \pm standard deviation of three experimental repeats. $\mathrm{P}<0.05$ was considered to indicate a statistically significant difference.

\section{Results}

$I L-1 \beta$ expression is increased in NSCLC tissues and cell lines. In order to investigate the level of IL-1 $\beta$ expression in NSCLC tissues and cell lines, RT-qPCR and western blot analyses were used. As shown in Fig. 1A, IL-1 $\beta$ mRNA expression was higher in tumor tissues compared with that in corresponding non-tumor tissues $(\mathrm{P}<0.01)$. Furthermore, the western blotting data also demonstrated that the protein expression level of IL-1 $\beta$ was higher in NSCLC samples than in normal lung tissue $(\mathrm{P}<0.01$; Fig. 1B). In addition, the expression of IL-1 $\beta$ was increased in NSCLC cell lines (A549, HCC827 and H1650), particularly in A549 cells, compared with that in the normal epithelial cell line BEAS-2B, at both the mRNA and protein levels (all $\mathrm{P}<0.01$; Fig. $1 \mathrm{C}$ and $\mathrm{D}$ ).

$I L-1 \beta$ regulates paclitaxel chemosensitivity in NSCLC cells. A549 cells were used for further experiments. To investigate the effect of IL-1 $\beta$ on paclitaxel sensitivity, cell viability and 
A
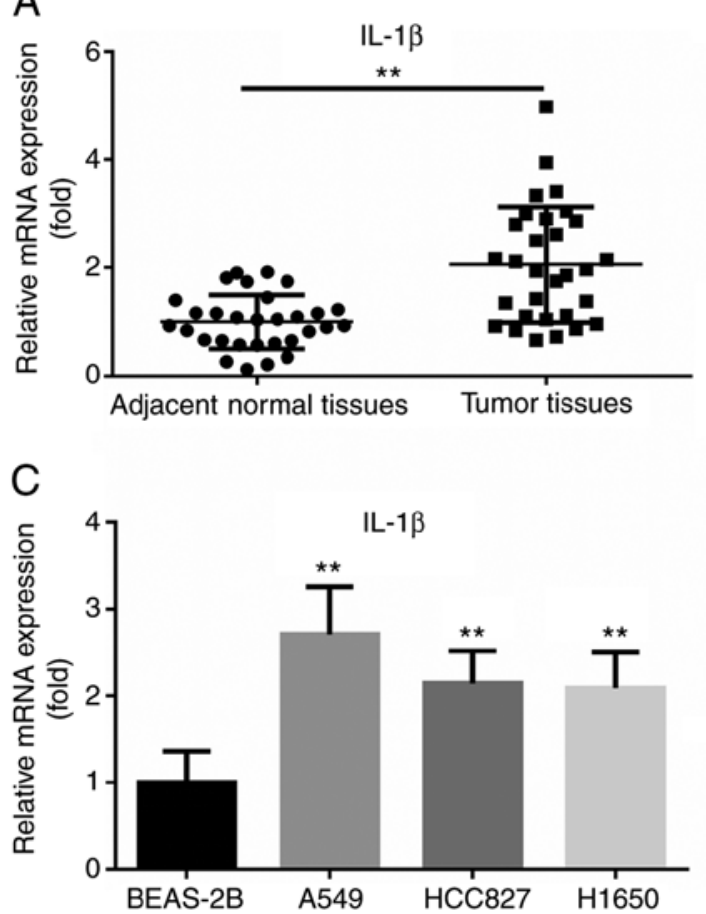

B
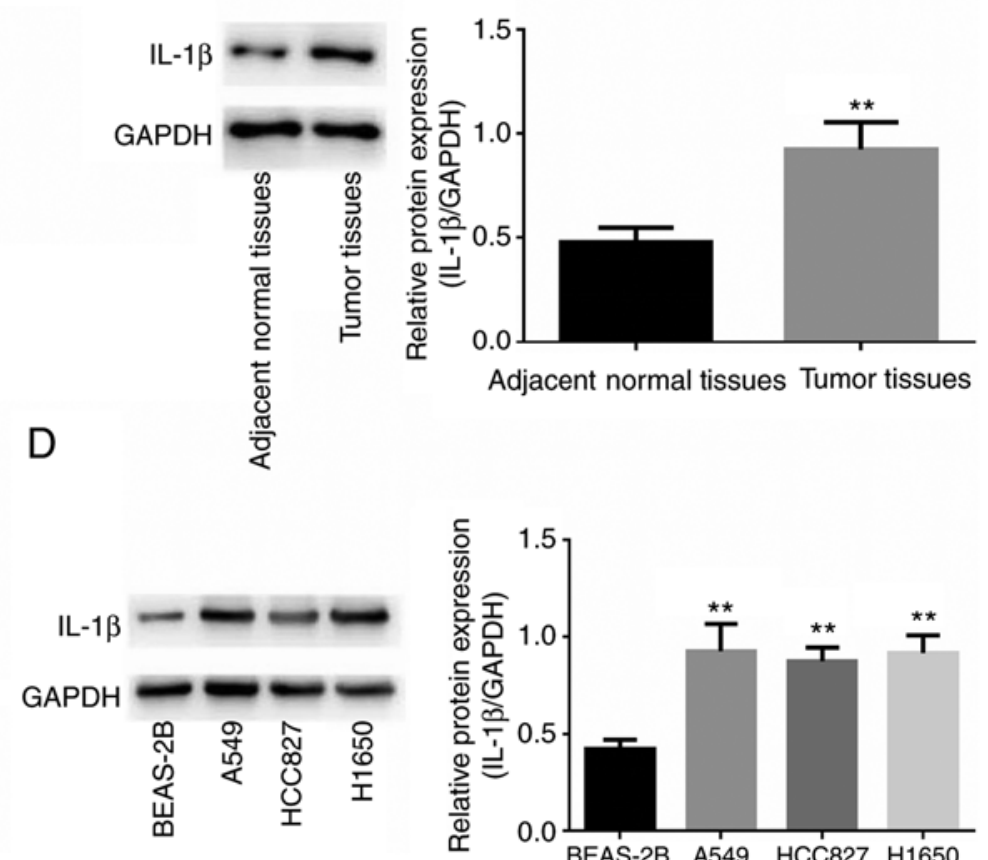

Figure 1. Upregulation of IL-1 $\beta$ in NSCLC tissues and cells. The expression of IL-1 $\beta$ in 30 NSCLC tissues and matched adjacent normal tissues was detected by (A) reverse transcription-quantitative PCR and (B) western blot analyses. ${ }^{* *} \mathrm{P}<0.01$ vs. adjacent normal tissue. The same methods were used to measure the (C) mRNA and (D) protein expression of IL-1 $\beta$ in the NSCLC cell lines A549, HCC827 and H1650 and the normal epithelial cell line BEAS-2B. ${ }^{* *} \mathrm{P}<0.01$ vs. BEAS-2B. Data are presented as the mean \pm SD. NSCLC, non-small cell lung cancer.

apoptosis were determined. The results demonstrated that cell viability was inhibited in the paclitaxel group, compared with the control group at 24 and $48 \mathrm{~h}(\mathrm{P}<0.01$; Fig. 2A), and increased in the paclitaxel + IL-1 $\beta$ group compared with the paclitaxel group at $48 \mathrm{~h}(\mathrm{P}<0.05$; Fig. $2 \mathrm{~A})$. Compared with the control group, cell apoptosis was induced by paclitaxel $(\mathrm{P}<0.01$; Fig. 2B) and inhibited by IL-1 $\beta(\mathrm{P}<0.05$; Fig. $2 \mathrm{~B})$. Compared with paclitaxel treatment, cell apoptosis was decreased after paclitaxel + IL-1 $\beta$ treatment $(\mathrm{P}<0.05$; Fig. $2 \mathrm{~B})$. These results indicated that IL-1 $\beta$ reduced the sensitivity of A549 cells to paclitaxel.

Association between IL-1 $\beta$ and autophagy in NSCLC cells. The activity of autophagy in A549 cells treated with IL-1 $\beta$ was examined. Tunicamycin is known to induce autophagy (19) and was used as a positive control in the present study. Western blot analysis results demonstrated that both tunicamycin and IL-1 $\beta$ treatment increased the expression of LC3-II and decreased the expression of P62 (Fig. 3A). Additionally, the effect of autophagy on the IL-1 $\beta$ level was investigated. The expression of IL-1 $\beta$ was found to be upregulated by tunicamycin treatment compared with the control group $(\mathrm{P}<0.01$; Fig. $3 \mathrm{~B})$. These results suggested that IL- $1 \beta$ induced cell autophagy and autophagy further enhanced IL-1 $\beta$ expression.

$I L-1 \beta$ regulates $N S C L C$ cell sensitivity to paclitaxel through controlling autophagy. Cell viability and apoptosis were detected by CCK-8 and flow cytometry assays in control, tunicamycin, paclitaxel and paclitaxel + tunicamycin groups. As presented in Fig. 4A and B, compared with the control group, tunicamycin promoted cell viability and suppressed apoptosis $(\mathrm{P}<0.05)$, whereas paclitaxel inhibited cell viability and promoted apoptosis $(\mathrm{P}<0.01)$. Furthermore, tunicamycin enhanced paclitaxel-induced cell viability $(\mathrm{P}<0.05)$ and repressed paclitaxel-induced apoptosis $(\mathrm{P}<0.01)$, as compared with the paclitaxel alone group. These results suggested that autophagy reduced the sensitivity of A549 cells to paclitaxel.

To further elucidate the association between IL-1 $\beta$ and paclitaxel sensitivity, control, paclitaxel, tunicamycin, IL-1 $\beta$, paclitaxel + tunicamycin and tunicamycin + paclitaxel + IL-1 $\beta$ groups were used. In Fig. 4C, western blot analysis revealed that as an autophagy inducer, tunicamycin significantly increased the formation of LC3-II and decreased the expression of P62 (both $\mathrm{P}<0.001)$. Further analysis revealed that paclitaxel inhibited the formation of LC3-II $(\mathrm{P}<0.01)$ and increased the expression level of P62 $(\mathrm{P}<0.001)$ in tunicamycin-treated A549 cells. Furthermore, IL-1 $\beta$ reversed the increased expression of P62 $(\mathrm{P}<0.05)$ induced by paclitaxel in tunicamycin-treated A549 cells. These data suggested that IL-1 $\beta$ reduced the paclitaxel sensitivity of A549 cells by inducing autophagy.

\section{Discussion}

The expression level of the pro-inflammatory cytokine IL-1 $\beta$ was found to be elevated in various types of cancer and tumor microenvironments, and it is associated with tumor development (20). However, it remains unclear whether it has beneficial or harmful effects (21). IL-1 $\beta$ has been reported to regulate malignant cell proliferation, migration, invasion and epithelial-to-mesenchymal transition $(22,23)$. Furthermore, it has been shown to mediate apoptosis by regulating caspase-3, poly ADP-ribose polymerase and 

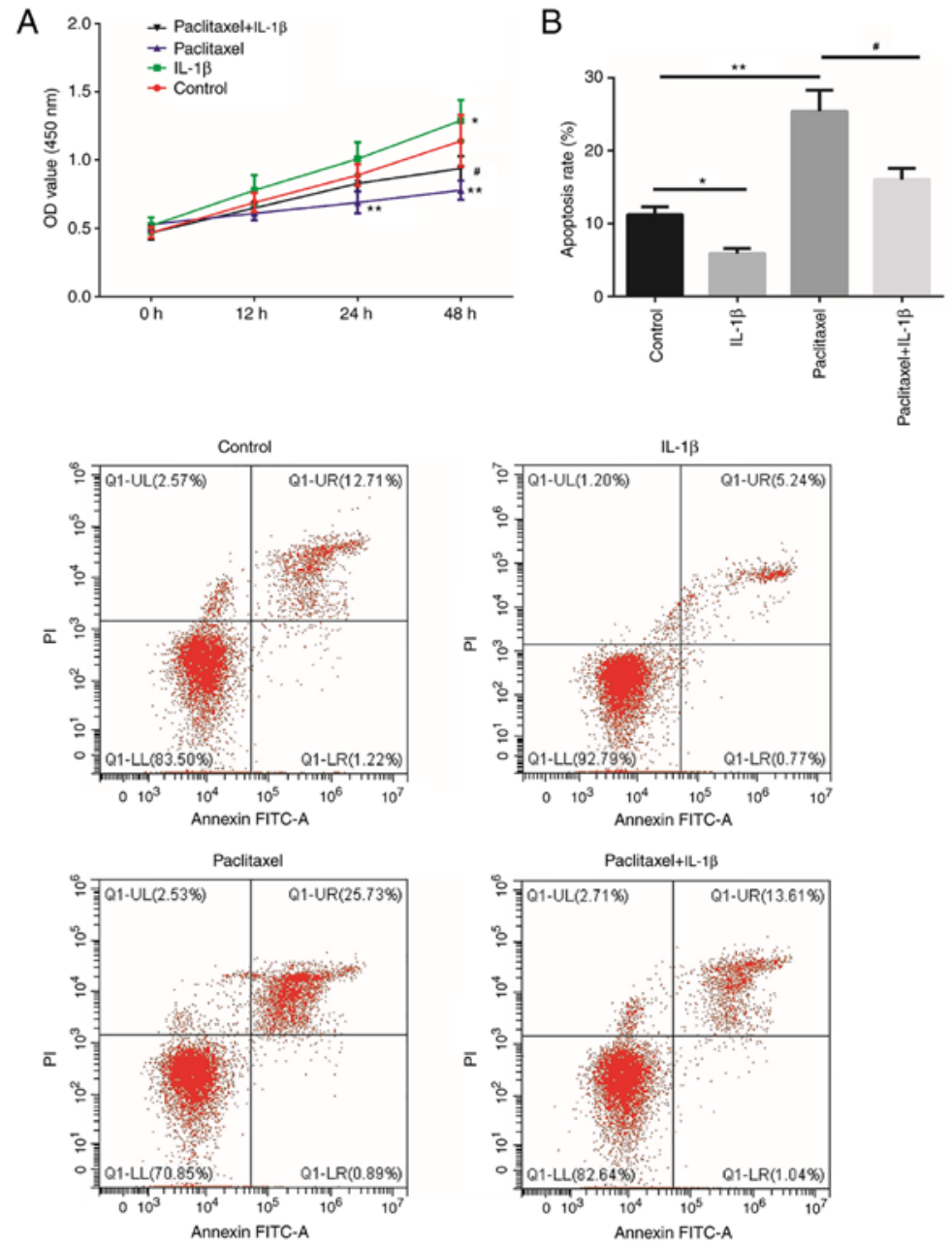

Figure 2. Effect of IL-1 $\beta$ on the sensitivity of NSCLC cells to paclitaxel. A549 cells were treated with paclitaxel or IL-1 $\beta$ alone, paclitaxel + IL-1 $\beta$ or control. (A) Cell Counting Kit-8 assay was used to evaluate cell viability. (B) Flow cytometry was used to evaluate cell apoptosis. Data are presented as the mean \pm SD. ${ }^{*} \mathrm{P}<0.05$ and ${ }^{* *} \mathrm{P}<0.01$ vs. control; ${ }^{*} \mathrm{P}<0.05$ vs. paclitaxel. NSCLC, non-small cell lung cancer; OD, optical density.
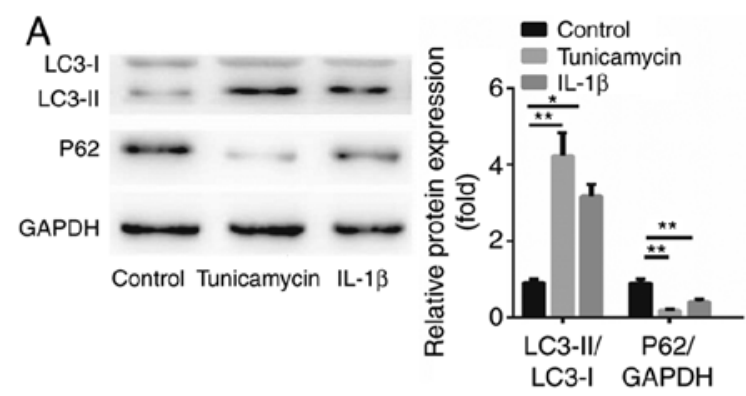

B

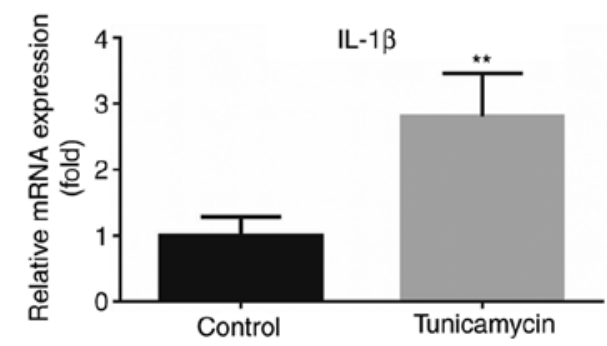

Figure 3. IL-1 $\beta$ expression and autophagy are interrelated factors in NSCLC cells. (A) After A549 cells were treated with IL-1 $\beta$ and tunicamycin, western blot analysis was performed to evaluate LC3 and P62 expression. GAPDH was used as the loading control. ${ }^{*} \mathrm{P}<0.05$ and ${ }^{* *} \mathrm{P}<0.01$. (B) Expression of IL- $1 \beta$ was measured by reverse transcription-quantitative PCR analysis in A549 cells following treatment with tunicamycin. Data are presented as the mean $\pm \mathrm{SD} .{ }^{* *} \mathrm{P}<0.01$ vs. control. NSCLC, non-small cell lung cancer. inhibitor of caspase-activated DNase (24), and Bcl-2 protein family members (25). In patients with lung cancer, IL-1 $\beta$ was found to be highly expressed (26), and it favors the establishment of an inflammatory microenvironment that increases the risk of lung cancer (22), meaning that it could be a potential biomarker of lung cancer prognosis (27). Paclitaxel is a well-known chemotherapeutic drug used for the treatment of NSCLC; however, chemoresistance has been observed, which compromises clinical efficacy and adversely affects the quality of life of the patients (28). Therefore, it is crucial to enhance the chemosensitivity of NSCLC cells to paclitaxel. IL-1 $\beta$ is involved in drug resistance or chemosensitivity (15-17); however, to the best of our knowledge, there are few studies on the association between IL-1 $\beta$ and paclitaxel. For example, IL-1 $\beta$ expression is upregulated in macrophages as a response to paclitaxel chemotherapy (29). Paclitaxel treatment causes IL-1 $\beta$ production by LPS-stimulated cells (30). In the present study, the association between IL-1 $\beta$ and paclitaxel sensitivity in NSCLC cells was investigated. First, it was observed that the expression of IL-1 $\beta$ was increased in both NSCLC tissues and cell lines, suggesting that IL-1 $\beta$ may act as a tumor promoter in NSCLC. Subsequently, IL-1 $\beta$ was shown to promote paclitaxel-suppressed cell viability and 
A
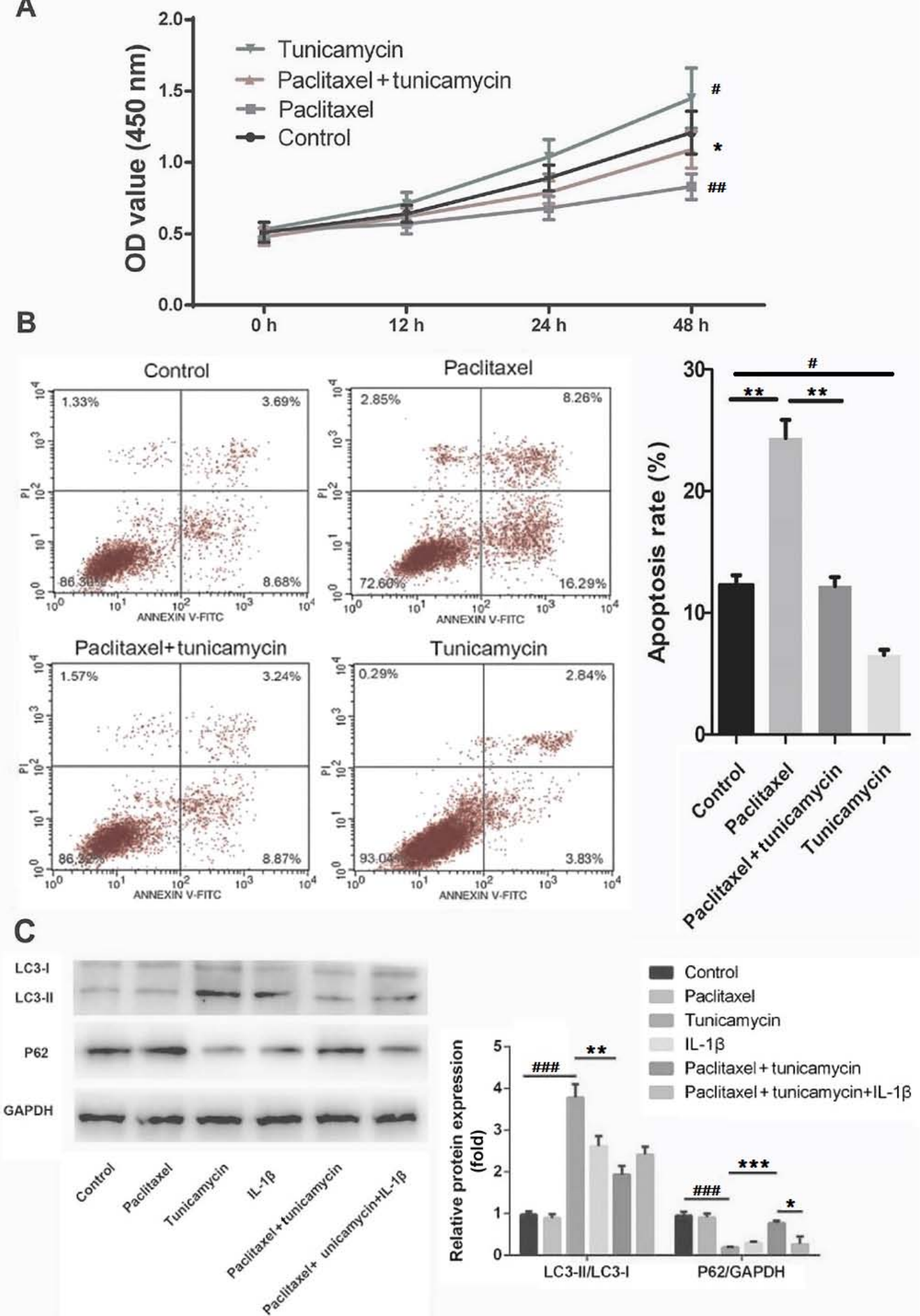

Figure 4. IL-1 $\beta$ modulates paclitaxel sensitivity of NSCLC cells via regulating autophagy. A549 cells were treated with tunicamycin, paclitaxel and tunicamycin + paclitaxel, and the (A) cell viability and (B) apoptosis were measured by using Cell Counting Kit-8 assay and flow cytometry, respectively. (C) A549 cells were treated with paclitaxel alone, tunicamycin, IL-1 $\beta$ alone, paclitaxel + tunicamycin and tunicamycin + paclitaxel + IL-1 $\beta$, and western blotting was performed to test LC3 and P62 protein expression levels. Data are presented as the mean $\pm \mathrm{SD} .{ }^{\#} \mathrm{P}<0.05,{ }^{\# \#} \mathrm{P}<0.01$ and ${ }^{\# \# \#} \mathrm{P}<0.001$ vs. control; ${ }^{*} \mathrm{P}<0.05^{* * *} \mathrm{P}<0.01$ and ${ }^{* * *} \mathrm{P}<0.001$ vs. paclitaxel $(\mathrm{B}) ;{ }^{*} \mathrm{P}<0.05,{ }^{* *} \mathrm{P}<0.01$ and ${ }^{* * * *} \mathrm{P}<0.001$ vs. paclitaxel + tunicamycin. NSCLC, non-small cell lung cancer.

inhibit paclitaxel-induced cell apoptosis, suggesting that IL-1 $\beta$ lowered paclitaxel sensitivity in NSCLC cells.

However, the underlying mechanism through which IL-1 $\beta$ affects paclitaxel sensitivity remains elusive. The present study revealed that IL-1 $\beta$ treatment was able to induce A549 cell autophagy, and that the cells treated with tunicamycin exhibited increased IL-1 $\beta$ levels. Autophagy is a conserved eukaryotic cellular degradation and recycling process, which 
may be subdivided into micro-autophagy, macro-autophagy and chaperone-mediated autophagy (31). Dysfunction of the autophagic pathway may promote aging and various diseases, including infections, cancer, neurodegeneration and heart disease (32). During the autophagy process LC3-I is converted to LC3-II, while when autophagy is decreased, the p62 level is increased (33). Autophagy plays a key role in the immune system as a regulator of inflammatory cytokines, particularly the release of IL-1 family members (34). A previous study reported that the IL-1 $\beta$ secretion pathway is affected by autophagy, which may be promoted by starvation or pharmacological drugs (35), and the results of the present study are consistent with this conclusion.

Autophagy occurs frequently during cancer chemotherapy, and is involved in the development of multidrug resistance (36). Drug resistance of cancer cells may be overcome by inhibiting autophagy, which enhances the efficacy of anticancer therapies (37). Previous studies revealed that autophagy mediates resistance or sensitivity to paclitaxel. For example, autophagy inhibition was reported to sensitize endometrial cancer cells to paclitaxel (38). In addition, inhibition of cell autophagy promoted paclitaxel-induced cell death, which improved the outcome of paclitaxel in the treatment of NSCLC (39). Furthermore, certain proteins and microRNAs may regulate paclitaxel sensitivity by inducing or inhibiting autophagy $(40,41)$. In the present study, it was observed that autophagy may decrease the sensitivity of NSCLC cells to paclitaxel. Furthermore, IL-1 $\beta$ decreased NSCLC cell sensitivity to paclitaxel through inducing autophagy. Thus, it may be hypothesized that regulation of IL- $1 \beta$ expression in NSCLC cells may alter the resistance to paclitaxel. To further verify the results of the present study, 3-methyladenine as an autophagy inhibitor will be used to observe whether IL-1 $\beta$ regulates autophagy via the PI3K pathway and reveal the unknown mechanism by which IL-1 $\beta$ regulates paclitaxel sensitivity.

In conclusion, the present study suggested that IL-1 $\beta$ may act as a tumor promoter in NSCLC. IL-1 $\beta$ decreased the sensitivity of A549 cells to paclitaxel via inducing autophagy, which was reflected by increased cell viability and decreased apoptosis. The results of the present study indicated that IL-1 $\beta$ may be a novel target for improving the therapeutic efficacy of paclitaxel chemotherapy in NSCLC.

\section{Acknowledgements}

Not applicable.

\section{Funding}

The present study was supported by the Xi'an Science and Technology Bureau's 'Science and Technology +' Action PlanMedical Research Project [grant no. 201805093YX1SF27(6)] and the corresponding supporting funds from Xi'an Chest Hospital.

\section{Availability of data and materials}

The datasets used and/or analyzed during the present study are available from the corresponding author on reasonable request.

\section{Authors' contributions}

JL, TH and YF conceived and designed the study. JD and ZL performed the experiments. JD and JX analyzed the data. JL and TH wrote and edited the manuscript. YF and TH confirm the authenticity of all the raw data. All authors read and approved the final manuscript.

\section{Ethics approval and consent to participate}

The present study was approved by the Ethics Committee of Xi'an Chest Hospital (Xi'an, China) and each participant provided written informed consent.

\section{Patient consent for publication}

Not applicable.

\section{Competing interests}

The authors declare that they have no competing interests.

\section{References}

1. Bray F, Ferlay J, Soerjomataram I, Siegel RL, Torre LA and Jemal A: Global cancer statistics 2018: GLOBOCAN estimates of incidence and mortality worldwide for 36 cancers in 185 countries. CA Cancer J Clin 68: 394-424, 2018.

2. Molina JR, Yang P, Cassivi SD, Schild SE and Adjei AA: Non-small cell lung cancer: Epidemiology, risk factors, treatment, and survivorship. Mayo Clin Proc 83: 584-594, 2008.

3. Rossi A and Di Maio M: Platinum-based chemotherapy in advanced non-small-cell lung cancer: Optimal number of treatment cycles. Expert Rev Anticancer Ther 16: 653-660, 2016.

4. Herbst RS, Morgensztern D and Boshoff C: The biology and management of non-small cell lung cancer. Nature 553: 446-454, 2018.

5. Zhang D, Yang R, Wang S and Dong Z: Paclitaxel: New uses for an old drug. Drug Des Devel Ther 8: 279-284, 2014.

6. Weaver BA: How Taxol/paclitaxel kills cancer cells. Mol Biol Cell 25: 2677-2681, 2014.

7. Ramalingam S and Belani CP: Paclitaxel for non-small cell lung cancer. Expert Opin Pharmacother 5: 1771-1780, 2004.

8. Joshi M, Liu X and Belani CP: Taxanes, past, present, and future impact on non-small cell lung cancer. Anticancer Drugs 25: 571-583, 2014.

9. Lu C, Xie Z and Peng Q: MiRNA-107 enhances chemosensitivity to paclitaxel by targeting antiapoptotic factor Bcl-w in non small cell lung cancer. Am J Cancer Res 7: 1863-1873, 2017.

10. Libby P: Interleukin-1 Beta as a target for atherosclerosis therapy: Biological basis of CANTOS and beyond. J Am Coll Cardiol 70: 2278-2289, 2017.

11. Lopez-Castejon $G$ and Brough D: Understanding the mechanism of IL-1 $\beta$ secretion. Cytokine Growth Factor Rev 22: 189-195, 2011.

12. Arranz L, Arriero MDM and Villatoro A: Interleukin-1 $\beta$ as emerging therapeutic target in hematological malignancies and potentially in their complications. Blood Rev 31: 306-317, 2017.

13. Azad N, Rojanasakul Y and Vallyathan V: Inflammation and lung cancer: Roles of reactive oxygen/nitrogen species. J Toxicol Environ Health B Crit Rev 11: 1-15, 2008.

14. Kim JW, Koh Y, Kim DW, Ahn YO, Kim TM, Han SW, Oh DY, Lee SH, Im SA, Kim TY, et al: Clinical implications of VEGF, TGF- $\beta 1$, and IL-1 $\beta$ in patients with advanced non-small cell lung cancer. Cancer Res Treat 45: 325-333, 2013.

15. Mendoza-Rodríguez MG, Ayala-Sumuano JT, García-Morales L, Zamudio-Meza H, Pérez-Yepez EA and Meza I: IL-1 $\beta$ inflammatory cytokine-induced TP63 isoform $\triangle \mathrm{NP} 63 \alpha$ signaling cascade contributes to cisplatin resistance in human breast cancer cells. Int J Mol Sci 20: E270, 2019. 
16. Feng X, Luo Q, Zhang H, Wang H, Chen W, Meng G and Chen F: The role of NLRP3 inflammasome in 5-fluorouracil resistance of oral squamous cell carcinoma. J Exp Clin Cancer Res 36: 81, 2017.

17. Lee CR, Kang JA, Kim HE, Choi Y, Yang T and Park SG: Secretion of IL-1 $\beta$ from imatinib-resistant chronic myeloid leukemia cells contributes to BCR-ABL mutation-independent imatinib resistance. FEBS Lett 590: 358-368, 2016.

18. Livak KJ and Schmittgen TD: Analysis of relative gene expression data using real-time quantitative PCR and the 2(-Delta Delta C(T)) method. Methods 25: 402-408, 2001.

19. Yang X, Srivastava R, Howell SH and Bassham DC: Activation of autophagy by unfolded proteins during endoplasmic reticulum stress. Plant J 85: 83-95, 2016.

20. Mendoza-Rodríguez M, Arévalo Romero H,Fuentes-Pananá EM, Ayala-Sumuano JT and Meza I: IL-1 $\beta$ induces up-regulation of BIRC3, a gene involved in chemoresistance to doxorubicin in breast cancer cells. Cancer Lett 390: 39-44, 2017.

21. Bhat IA, Naykoo NA, Qasim I, Ganie FA, Yousuf Q, Bhat BA Rasool R, Aziz SA and Shah ZA: Association of interleukin 1 beta (IL-1 $\beta$ ) polymorphism with mRNA expression and risk of non small cell lung cancer. Meta Gene 2: 123-133, 2014.

22. Lee CH, Chang JS, Syu SH, Wong TS, Chan JY, Tang YC, Yang ZP, Yang WC, Chen CT, Lu SC, et al: IL-1 $\beta$ promotes malignant transformation and tumor aggressiveness in oral cancer. J Cell Physiol 230: 875-884, 2015.

23. Zhang Q, Wang H, Mao C, Sun M, Dominah G, Chen L and Zhuang Z: Fatty acid oxidation contributes to IL-1 $\beta$ secretion in M2 macrophages and promotes macrophage-mediated tumor cell migration. Mol Immunol 94: 27-35, 2018

24. Wang C, Wang MW, Tashiro S, Onodera S and Ikejima T: IL-1beta acts in synergy with endogenous IL-1beta in A375-S2 human melanoma cell apoptosis through mitochondrial pathway. J Korean Med Sci 20: 555-561, 2005.

25. Guadagno J, Swan P, Shaikh R and Cregan SP: Microglia-derived IL-1 $\beta$ triggers p53-mediated cell cycle arrest and apoptosis in neural precursor cells. Cell Death Dis 6: e1779, 2015.

26. Matanić D, Beg-Zec Z, Stojanović D, Matakorić N, Flego V and Milevoj-Ribić F: Cytokines in patients with lung cancer. Scand J Immunol 57: 173-178, 2003.

27. Vikhreva P, Petrova V, Gokbulut T, Pestlikis I, Mancini M, Di Daniele N, Knight RA, Melino G and Amelio I: TAp73 upregulates IL-1 $\beta$ in cancer cells: Potential biomarker in lung and breast cancer? Biochem Biophys Res Commun 482: 498-505, 2017.

28. d'Amato TA, Landreneau RJ, McKenna RJ, Santos RS and Parker RJ: Prevalence of in vitro extreme chemotherapy resistance in resected nonsmall-cell lung cancer. Ann Thorac Surg 81: 440-446; discussion 446-447, 2006
29. Voloshin T, Alishekevitz D, Kaneti L, Miller V, Isakov E, Kaplanov I, Voronov E, Fremder E, Benhar M, Machluf M, et al: Blocking IL1 $\beta$ Pathway following paclitaxel chemotherapy slightly inhibits primary tumor growth but promotes spontaneous metastasis. Mol Cancer Ther 14: 1385-1394, 2015.

30. Wong J, Tran LT, Magun EA, Magun BE and Wood LJ: Production of IL-1 $\beta$ by bone marrow-derived macrophages in response to chemotherapeutic drugs: Synergistic effects of doxorubicin and vincristine. Cancer Biol Ther 15: 1395-1403, 2014.

31. Parzych KR and Klionsky DJ: An overview of autophagy: Morphology, mechanism, and regulation. Antioxid Redox Signal 20: 460-473, 2014.

32. Levine B and Kroemer G: Autophagy in the pathogenesis of disease. Cell 132: 27-42, 2008.

33. Tanida I and Waguri S: Measurement of autophagy in cells and tissues. Methods Mol Biol 648: 193-214, 2010.

34. Harris J, Lang T, Thomas JPW, Sukkar MB, Nabar NR and Kehrl JH: Autophagy and inflammasomes. Mol Immunol 86: 10-15, 2017.

35. Claude-Taupin A, Bissa B, Jia J, Gu Y and Deretic V: Role of autophagy in IL-1 $\beta$ export and release from cells. Semin Cell Dev Biol 83: 36-41, 2018.

36. Li YJ, Lei YH, Yao N, Wang CR, Hu N, Ye WC, Zhang DM and Chen ZS: Autophagy and multidrug resistance in cancer. Chin J Cancer 36: 52, 2017.

37. Kumar A, Singh UK and Chaudhary A: Targeting autophagy to overcome drug resistance in cancer therapy. Future Med Chem 7: $1535-1542,2015$

38. Liu S and Li X: Autophagy inhibition enhances sensitivity of endometrial carcinoma cells to paclitaxel. Int J Oncol 46: 2399-2408, 2015.

39. Chen K and Shi W: Autophagy regulates resistance of non-small cell lung cancer cells to paclitaxel. Tumour Biol 37: 10539-10544, 2016.

40. Wang Z, He R, Xia H, Wei Y and Wu S: Knockdown of STMN1 enhances osteosarcoma cell chemosensitivity through inhibition of autophagy. Oncol Lett 13: 3465-3470, 2017.

41. Ran X, Yang J, Liu C, Zhou P, Xiao L and Zhang K: MiR-218 inhibits HMGB1-mediated autophagy in endometrial carcinoma cells during chemotherapy. Int J Clin Exp Pathol 8: 6617-6626, 2015.

This work is licensed under a Creative Commons Attribution-NonCommercial-NoDerivatives 4.0 International (CC BY-NC-ND 4.0) License. 